\title{
Development of Thematic Learning Materials Based on Jepara's Local Wisdom on the Theme "Daerah Tempat Tinggalku” for Grade 4 Students of Primary Schools
}

\author{
Sri Utaminingsih ${ }^{1}$, Murtono $^{2}$, Hamidaturrohmah ${ }^{3}$ \\ \{sri.utaminingsih@umk.ac.id ${ }^{1}$,murtono@umk.ac.id ${ }^{2}$,hamidaturrohmah1304@gmail.com ${ }^{3}$ \} \\ ${ }^{1,2,3}$ Faculty of Teaching and Education, Universitas Muria Kudus Gondang Manis PO.BOX 53 Bae, \\ Kudus, Central Java Indonesia Phone (+62291) 438229, Fax (+62291) 437198
}

\begin{abstract}
This study aims to describe the analysis of the needs of teachers and students of teaching materials, describe the process of developing thematic teaching materials based on Jepara local wisdom, and test the effectiveness of the teaching materials developed. This research was conducted in Semai Elementary School, SDN 1 Kecapi, SDN 2 Senenan, SDN 3 Senenan, SDN 5 Kecapi as the experimental group and SD N 1 Senenan, SD N 2 Kecapi, SD N 4 Kecapi, SD N 6 Kecapi, and SD N 7 Kecapi as a control group in Jepara Regency. The method of research and development of these thematic teaching materials using the Borg $\&$ Gall model includes the preliminary study phase, planning, developing the initial draft of the product, expert testing, revision of expert test results, limited trials, improvement of limited trials. The results of expert validation from aspects of the content and language aspects obtained a score of 91 on average 3.64 percent $91 \%$ with very good categories. The results of the validation from the media aspect scored 54 on average 3.6 percent $90 \%$ with very good categories. The results of testing the effectiveness of teaching materials based on local wisdom of Jepara Regency were obtained from the results of the $t$ test in the experimental group and the control group namely 11,036>1,969, so Ho was rejected and Ha was accepted. Based on the results of validation, teacher and student responses and t-test, it can be concluded that the development of local wisdom-based teaching materials in Jepara is effective and suitable for use in learning.
\end{abstract}

Keywords: Teaching Materials, Thematic Learning, Local Wisdom

\section{Introduction}

Modern civilization with the Industrial Revolution 4.0 or millennial era is experiencing various developments. His various attractions and propaganda must be responded critically especially to the increasingly widespread hate speech or hoax news that can anesthetize a person so that he forgets his identity and identity as an Indonesian nation. The edges are the erosion of the values of local wisdom and regional culture. According to Mungmachon (2012) the existence of outside influences that enter and then spread within the community makes the values of local wisdom and regional culture fade and can cause many hard environmental and social problems.

In line with the opinion of Hidayati (2016) which states that the fading of local wisdom has caused a shift in behavior and culture among the people. This makes the importance of strengthening local wisdom for the people of Indonesia. Strengthening local wisdom is a buffer against the development of the industrial revolution 4.0. Because it will function as a 
weapon in responding and answering the currents of the times. Local wisdom is scholarship of the wealth of an area in the form of knowledge, beliefs, norms, customs, culture, insights and so on which are inherited and maintained as an identity and guidance in teaching us to act appropriately in life (Utari, 2016). 
One example of a region where local wisdom needs to be maintained as a city identity is Jepara. The area known as the carving city began to experience a grave regeneration crisis. This has an impact on the existence of the wisdom of carving culture which became a superior potential began to be eroded by the times (Saidah, 2017). This phenomenon has occurred, making educational institutions feel lost space. Education should have an important role in determining the change and development of the way of thinking of society, especially for the development of the nation and state.

As the birthplace of R.A Kartini, education in Jepara should have more value and quality, so that it can produce a golden generation that is superior, skilled, characterized and able to preserve and preserve local wisdom from the legacy of its predecessors such as Ratu Kalinyamat, Ratu Shima and R.A.Kartini. The three female figures are pioneers who have made Jepara a prosperous, strong, and well-known area for its carving to foreign countries.

One way that can be taken to preserve and preserve the local wisdom of an area is by implementing education based on local wisdom. Local wisdom-based education means education that teaches students to stay close to the concrete situations they face everyday. According to Setiawan (2008: 30) education based on local wisdom (local wisdom) makes someone feel optimistic about the creation of education that is able to provide spirit and meaning for human life in Indonesia.

Education problems so far are the sources and teaching materials related to local culture are still minimal (Oktavianti et al, 2017). This is consistent with information obtained on January 5, 2019 from the results of interviews conducted with the fourth grade teachers of Semai Elementary School, SD Negeri 2 Senenan, SD Negeri 3 Senenan, SD Negeri 1 Kecapi, and SD Negeri 5 Kecapi that schools do not have specific guidelines (teaching materials) in delivering material related to the preservation of Jepara's local wisdom. While teaching materials used in learning are still general in nature, there is no local wisdom content in the area where students live.

According to the results of Muktadir's research (2017) the existence of cultural similarities taught by teachers, will accelerate students' understanding of the material presented and learning to be effective. Therefore in schools there needs to be lessons that contain material based on local wisdom to prevent the loss of local wisdom of an area. Local wisdom as one thing that needs to be preserved so as not to become extinct. According to Kasa (2011) "the important of local wisdom must also be considered as one of supporting efforts of decreasingly natural environment". This means that the importance of local wisdom must also be considered as an effort to support the natural environment which is declining naturally.

In accordance with the results of the study (Tanjung and Fahmi, 2016) which state that the implementation of the 2013 curriculum implies learning by raising local wisdom as material that needs to be developed, the researcher intends to develop thematic teaching materials based on local wisdom in Jepara Regency in fourth grade students in elementary schools as a solution the problems that have been described

\section{Methodology}

The research was carried out at SD Semai (20 students), SDN 1 Kecapi (28 students), SDN 2 Senenan (35 students), SDN 3 Senenan (26 students), SDN 5 Kecapi (23 students) as the experimental group and SDN 1 Senenan (25 students), Kecapi 2 SDN (28 students), Kecapi 4 SDN (30 students), Kecapi 6 SDN (28 students), and Kecapi 7 SDN (11 students) as a control group in the Annual District of Jepara Regency.

The research and development method of this thematic teaching material uses the Borg \& Gall model which includes preliminary study stages, planning, initial product draft development, expert testing, revised expert test results, limited trials, refinement of limited trials (Sugiyono, 2016: 35). This teaching material is in the form of a teacher's book and a 
learning cd that contains a local wisdom video in Jepara Regency which is validated by expert judgment.

Data collection instruments used in this study were observation sheets, open interview guidelines, expert validation sheets, teacher response questionnaires, test questions sheets and documents. The test instrument for evaluating learning outcomes in this study, before being tested on students, the feasibility test will be tested first by looking at the validity, reliability, difficulty level and distinguishing features of the questions.

The test results of the test instruments showed that 30 items were valid with sufficient, good, and very good validity. The instruments tested have high reliability criteria in the amount of 0.657 and $r$ table in the amount of 0.266 . So it can be concluded that $r$ count> $r$ table is declared reliable. Based on the results of the test of distinguishing power about the matter obtained by distinguishing power 30 items with very good criteria. In addition, the test instruments tested also had an easy and medium difficulty level.

Data obtained in this study were analyzed using qualitative and quantitative analysis. Data analyzed included need analysis data, the feasibility of teaching materials and the effectiveness of teaching materials. Data from observations, interviews, and questionnaires as a needs analysis for the development of teaching materials were analyzed using qualitative data analysis techniques based on the opinion of Miles and Huberman (2014: 12-14) which included 3 stages, namely data condensation (data condensation), data display (data presentation), conclusion drawing / verification (drawing conclusions / verification).

Data on the feasibility of thematic teaching materials based on Jepara's local wisdom was obtained from expert validation, questionnaire responses from teachers and students in the form of quantitative data. Quantitative data is then converted into qualitative data. The total score obtained is then converted into a scale of four with the following categories:

\begin{tabular}{|c|c|}
\hline Conversion Value & Classification \\
\hline $81 \%-100 \%$ & Very good \\
\hline $61 \%-80 \%$ & Well \\
\hline $41 \%-60 \%$ & Enough \\
\hline $0 \%-40 \%$ & Less \\
\hline
\end{tabular}

Assessment is said to meet the criteria if the minimal category achieved is good. An analysis of the effectiveness of Jepara's local wisdom-based thematic teaching materials was carried out using a t-test.

\section{Results and Discussion}

The initial stage of this research and development is an analysis of the need for teaching materials conducted by observation and interviews with fourth grade students of elementary schools, observations and interviews with fourth grade teachers of elementary schools, and questionnaires given to fourth grade elementary school teachers and dabin 2 Annual Districts of Jepara Regency . Observations, interviews and questionnaires were carried out on November 4-6, 2018, January 5-8, 2019.

Based on data needs obtained from observations in five schools, Semai Elementary School an average of 2.47, SD Negeri 1 Kecapi an average of 2.39, SD Negeri 2 Senenan an average of 2.45, SD Negeri 3 Senenan on average 2.43, and Kecapi Public Elementary School 5 an average of 2.4. So it can be concluded that the average of the five schools scored less than 3 with enough categories.

Overall from the results of observations and interviews with students during thematic learning in class shows the attitude of students who have not been able to actively participate in learning because the material learned is a new thing that has never been known. Students also rarely get contextual material according to the local wisdom of the area where they live. The material taught is in accordance with the material in student 
books, worksheets, or Bupena which makes students still experience a little difficulty in understanding it. This is because the material is far from where students live.

Whereas ideal learning is characterized by its nature which emphasizes the process of empowering students actively, the learning process that provides meaningful understanding, and can be learning outcomes can be applied in everyday life. This is in line with what was stated by Suyitno et al (2015) that meaningful learning can be created through learning based on local wisdom. By utilizing the potential of local wisdom in the neighborhood where students live, the benefits of learning can be more felt, because the results of learning can be applied in everyday life.

For the results observations of teacher needs for thematic teaching materials obtained results from five schools namely SD Semai an average of 2.86, SD Negeri 1 Kecapi an average of 2.28, SD Negeri 2 Senenan an average of 2.57, SD Negeri 3 Senenan an average of 2.43, and SD Negeri 5 Kecapi an average of 2.28. From these data it can be concluded that the average of the five schools scored less than 3 with enough categories.

The results of the observation were strengthened by interviews with teachers that in carrying out thematic learning in schools still need a guide book containing complete material accompanied by strategies and methods that are able to create active and enjoyable learning. In addition, the material presented is also able to stimulate students to ask questions and give opinions. One stimulus that can be given is to link material to the local wisdom of the area where students live, because local wisdom of the region is concrete, close to students, and that students have seen before.

This is supported by the opinion of Shufa (2018) which states that learning based on local wisdom is very important to be applied by teachers in learning that is useful for increasing students' knowledge and understanding. According to Northcote, et al (2014) the integration of local cultural values in curriculum development such as setting learning objectives, designing teaching materials, determining learning strategies, learning media, and evaluating learning are important for quality of learning.

The results of the teacher's questionnaire, the results obtained that the teacher needs teaching materials based on local wisdom Jepara. The existence of teaching material that contains many interesting learning methods and contextual material in accordance with the area where students live and school environment is located, because it will facilitate students in understanding learning material. In addition, the display of teaching materials uses many colors to make it interesting, comic sans writing for easy reading and font size 12. Jepara's local wisdom-based teaching materials are also accompanied by cultural videos around Jepara.

Judging from the results of the needs of students and teachers, an effort was made to develop teaching materials based on local wisdom according to the area where students live and the school environment is located. Because the initial experience gained by students is the basis for implementing learning (Duncon, 2014).

This is also in line with the opinion of Meliono (2011) which states that local wisdom is the right teaching material for the education of Indonesia's young generation because they build several values such as nationalism, harmony, and morals to build identity. Prior to development, learning resources that are commonly used by grade IV elementary school teachers are first analyzed by researchers and teachers. The following components are teacher and student worksheets:

\begin{tabular}{|l|l|}
\hline The Ministry of Education and Culture Teacher's Book & \multicolumn{1}{|c|}{ Book LKS Maestro and Eksis } \\
\hline $\begin{array}{l}\text { Study Instructions } \\
\text { (instructions for teachers in using books) }\end{array}$ & $\begin{array}{l}\text { Work instructions } \\
\text { (procedural steps on how to carry out } \\
\text { learning activities) }\end{array}$ \\
\hline $\begin{array}{l}\text { Competencies that must be achieved: } \\
\text { - Core Competencies }\end{array}$ & $\begin{array}{l}\text { Competencies that must be achieved: } \\
\text { Basic competencies }\end{array}$ \\
\hline
\end{tabular}




\begin{tabular}{|l|l|}
\hline Basic competencies & \\
\hline $\begin{array}{l}\text { Supporting Information } \\
\text { - Media / Tools and Learning Resources } \\
\text { Examples of grading rubrics }\end{array}$ & Summary of contents of learning material \\
\hline $\begin{array}{l}\text { Work Instructions } \\
\text { (procedural steps on how to carry out learning } \\
\text { activities) }\end{array}$ & $\begin{array}{l}\text { Practice exercises } \\
\text { (MCQs, stuffing questions, project } \\
\text { assignments, products) }\end{array}$ \\
\hline Fill learning materials according to KI and KD & \\
\hline $\begin{array}{l}\text { Exercises (assignments in the form of projects, } \\
\text { products) }\end{array}$ & \\
\hline $\begin{array}{l}\text { Evaluation } \\
\text { (to measure how far the mastery of student } \\
\text { competencies) }\end{array}$ & \\
\hline
\end{tabular}

This teaching material was developed by linking the theme materials of class IV grade IV elementary school with local wisdom of Jepara which is the area where students live and the school environment is located. The following components are found in the development of teaching materials based on local wisdom in Jepara Regency:

\begin{tabular}{|l|}
\hline \multicolumn{1}{|c|}{ Development of Jepara Local Wisdom Based Learning Materials } \\
\hline Study Instructions \\
\hline Competencies that must be achieved: \\
- Core Competencies \\
- Basic competencies \\
- Learning objectives \\
- Development of Indicators \\
The indicator map displays all the material that is the focus of each lesson. Indicator maps \\
can connect and facilitate teacher's thought flow in presenting and managing learning. \\
Students can also follow the pattern by integrating based on the themes raised. \\
\hline Supporting Information \\
- Media / Tools and Learning Resources \\
(adjusted to the learning activities in Jepara's local wisdom-based teaching materials) \\
- In the supporting information section examples of assessment rubrics are not included \\
because they are already in the integrated government and thematic teacher book. From the \\
results of the analysis of the need for teaching materials shows that examples of assessment \\
rubrics are not the main needs, because teachers can easily get them from the internet or \\
other assessment books. \\
\hline Work Instructions \\
(procedural steps on how to implement learning activities tailored to Jepara's local wisdom- \\
based material) \\
\hline Fill learning material \\
- Adapted to CC and BC \\
- Accurate (material adapted to facts and data from local concepts / realities) \\
- Current (actual material presented in accordance with scientific developments and student \\
characteristics). \\
- Foster a love character for the local culture in the area where students live (Jepara). \\
- Language in the material is straightforward, communicative, interactive and appropriate for \\
student development \\
Practice \\
\hline Student worksheets (assignments, projects and products) \\
The practice questions are presented in the form of student worksheets and practice \\
questions at the end of the sub-theme. Student worksheets are intended to make it easier for \\
teachers to provide assignments, projects that are useful to support the achievement of \\
learning objectives. With worksheets, students can easily understand the tasks and projects \\
that are given, so that in doing so students become enthusiastic, responsible, and good \\
results.
\end{tabular}




\begin{tabular}{|l|}
\hline $\begin{array}{l}\text { Evaluation } \\
\text { (More clarified and detailed using sub-load lessons and basic competencies) }\end{array}$ \\
\hline Bibliography \\
\hline Writer biography \\
\hline
\end{tabular}

\section{Introduction}

In Jepara's local wisdom-based teaching materials, the introduction includes a learning guide component that serves to facilitate teachers in using books. In addition to the instructions, there are also core competencies, basic competencies, learning objectives to be achieved by students, indicators as benchmarks to find out the learning outcomes to be achieved by students, and supporting information in the form of media or tools used in the implementation of learning.

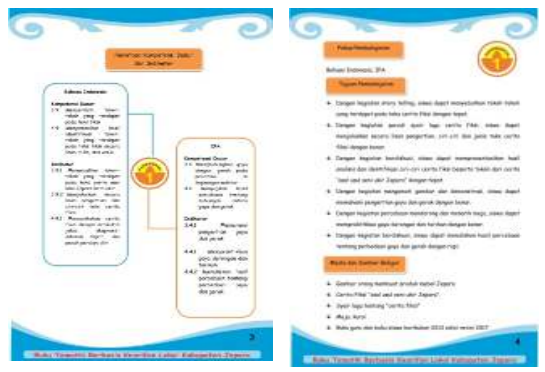

Figure 1.1 Introduction Section of Jepara's Local Wisdom-Based Teaching Material

\section{The core part of learning}

At the core of learning there are: (1) work instructions containing procedural steps in carrying out a series of learning activities so that they run systematically. (2) the contents of learning materials that are adapted to $\mathrm{KI}$ and $\mathrm{KD}$, accurate, up-to-date, foster the character of love for the local culture of the area where students live (Jepara), the language in the material is straightforward, communicative, interactive and in accordance with student development

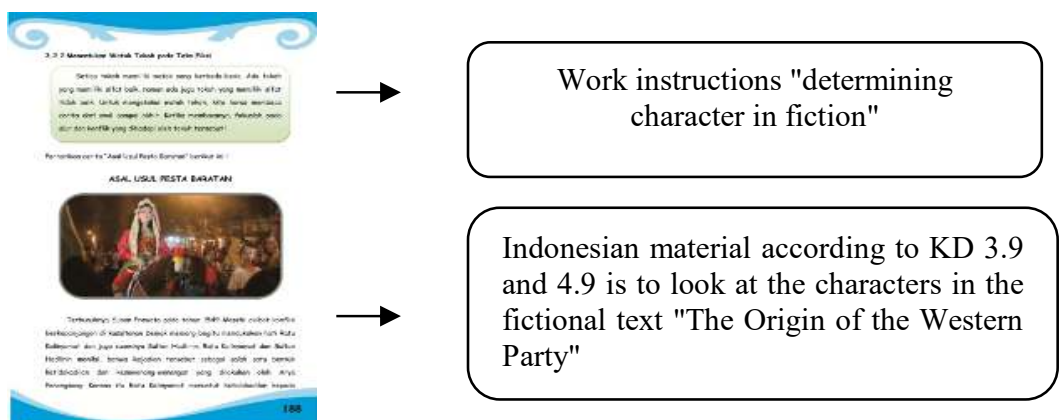

Figure 1.2 Examples of core material in Jepara's local wisdom-based thematic teaching materials

(3) practice questions are presented in the form of student worksheets and practice questions at the end of the sub-theme. Student worksheets are intended to make it easier for teachers to provide assignments, projects that are useful to support the achievement of learning objectives. With worksheets, students can easily understand the tasks and projects 
that are given, so that in doing so students become enthusiastic, responsible, and good results.

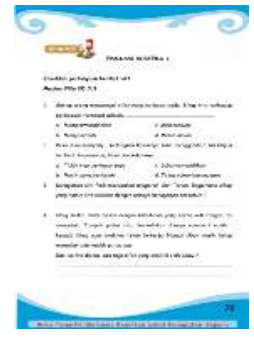

Figure 1.3

Practice questions at the end of the sub-theme

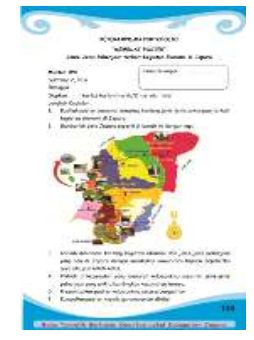

Figure 1.4

Student LKPD

\section{End / Final Section}

Inclusion of bibliography is intended as a responsibility of the existing citations in teaching materials and provide information to the reader if the reader wants to know more about the material presented.

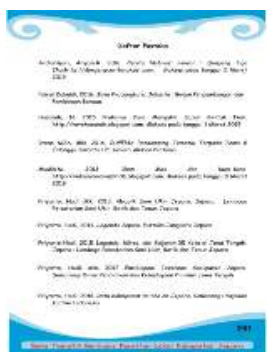

Figure 1.5.Bibliography Bibliography Based on Local Wisdom in Jepara

After teaching materials are developed, expert validation is carried out. The results of expert validation from material and language aspects obtained an average score of 91.64 percentage $91 \%$ with a very good category. The results of the validation of the media aspects obtained a score of 54 on average 3.6 percentage $90 \%$ with a very good category. After being validated, the teaching material was revised according to the validator's suggestion. In general teaching materials are appropriate to be used in learning it's just that teaching materials need to be revised in the following sections :

1) Revised teaching materials in the cover section of teaching materials need to be revised to be more interesting

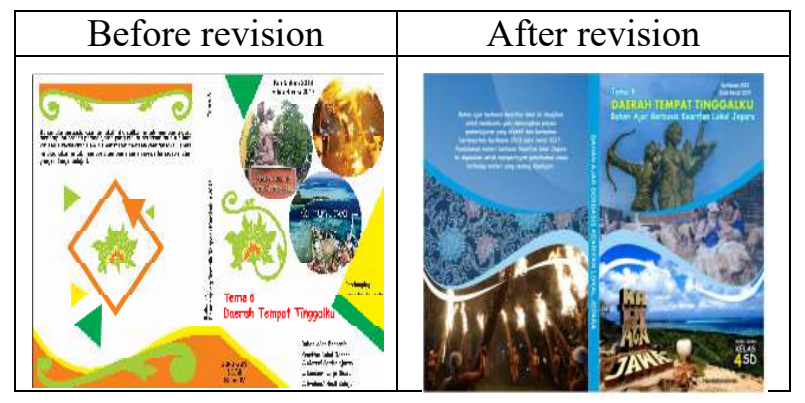


2) The teaching material is revised in the writing section of the influence of the style of "making fish creations from plasticine" is converted into an image in accordance with the local wisdom of Jepara namely the thread woven by craftsmen into troso cloth.

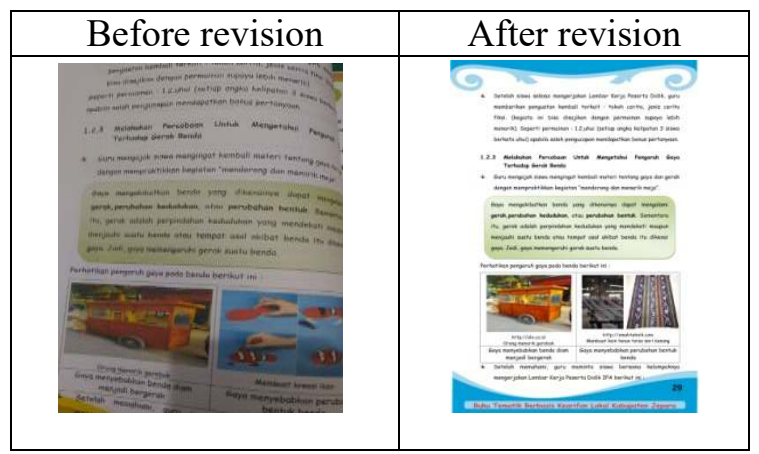

3) The third revision is the writing of $\mathrm{KD}$, indicators are made for mapping such as in the Ministry of Education and Culture teacher book and the colors of teaching materials must be bright and attractive

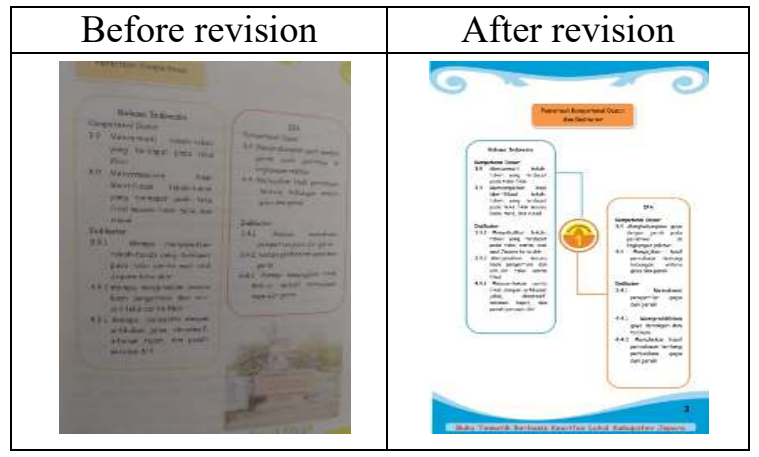

4) The fourth revision in the text section "adapted from" to "abstracted from"

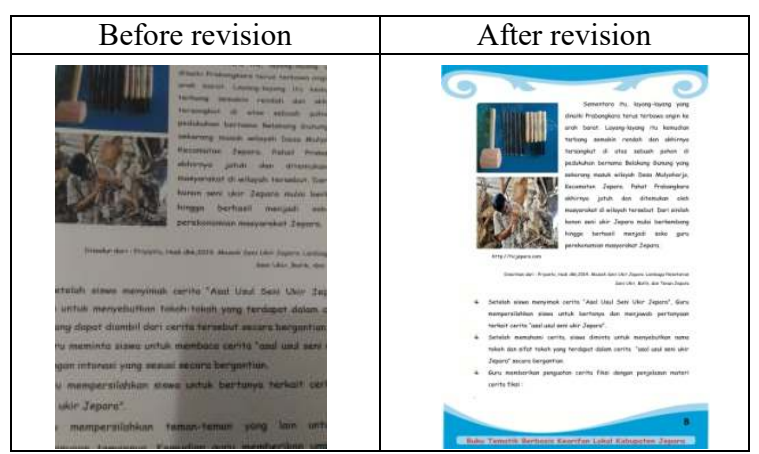


After being validated and revised, local wisdom-based teaching materials in Jepara Regency were tested in the experimental group, namely class IV SD Semai, SDN 1 Kecapi, SDN 2 Senenan, SDN 3 Senenan, and SDN 5 Kecapi by providing treatment which was carried out in May 2019. After completion treatment, students were given a post-test problem. Whereas the control group was only given a matter of posttest without any treatment. Product trial activities produce data on the effectiveness of teaching materials based on local wisdom in Jepara Regency. The results of student learning assessments are obtained by giving multiple choice questions totaling 30 questions to grade IV students. Questions were given to students in the experimental and control groups.

After completing the post-test, the next step is to calculate the test scores of the experimental group and the control group. Student grades show good results. The experimental group the mean value is greater than the average value of the control group. The following data is the value of the experimental group and the control group

Table 1.1 Experimental Group and Control Group Value Data

\begin{tabular}{|l|l|c|c|}
\hline No. & Value & $\begin{array}{c}\text { Experimental } \\
\text { Group }\end{array}$ & Control Group \\
\hline 1. & Nilai Tertinggi & 97 & 87 \\
\hline 2. & Nilai Terendah & 60 & 40 \\
\hline 3. & Nilai Rata-rata & 78,8 & 64,7 \\
\hline
\end{tabular}

Source: Researcher (Primary Data)

Based on the above table, the values of the experimental and control groups can be presented in the diagram as follows:

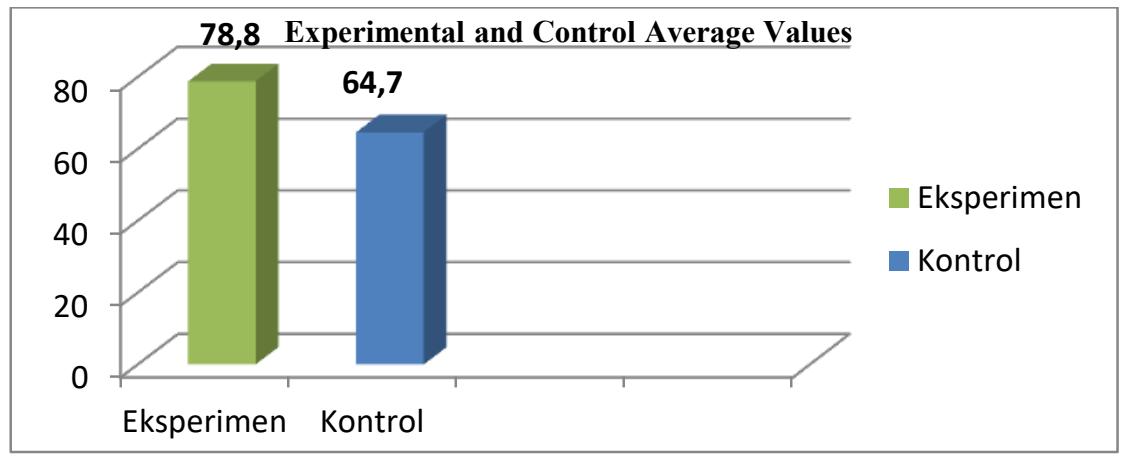

Based on these diagrams, it can be seen that the effectiveness data in the use of teaching materials applied in learning experience significant differences. This can be seen in the diagram that shows the differences between the experimental group and the control group. The diagram shows that the average value of the experimental group is greater than the control group. From the average value, it shows that the use of Jepara's local wisdom-based teaching materials is effectively used in learning.

Then a prerequisite test is performed to see whether data is normally distributed or not, homogeneous data groups or not and also limited field trials. The normality test results obtained with a significance value $\alpha=5 \%=0.05$. In the experimental group the values obtained were $0.058>0.05$ then Ho was accepted and normally distributed. In the control group of $0.083>0.05$, Ho was accepted and distributed normally. Based on the normality test, it can be obtained that the data is normally distributed. The next stage is homogeneity test, homogeneity test is done to describe whether the two groups have the same variance or not. Homogeneity test results showed that the significance was $0.183>0.05$. From these 
data it can be concluded that the group has the same variance.

The final step is determining the effectiveness of Jepara's local wisdom-based teaching materials. To test the effectiveness of teaching materials is done using t-test. Based on the ttest obtained $t$ count $>t$ table is 11.036 $>1.969$ then $\mathrm{Ha}$ is accepted. So it can be concluded that the use of Jepara-based local wisdom teaching materials is effectively applied in class IV of Jepara Regency elementary school.

The effectiveness of teaching materials is also strengthened by the results of research conducted by Suherman (2016) in his research entitled "Development of Local WisdomBased Teaching Materials (AIQ Nyereng Tunjung Tilah Empak Bau) on the Theme of Getting to Know the Surrounding Natural Environment in Class III MI Mambaul Khair Mataram City" shows that teaching materials based on local wisdom (AIQ Nyereng Tunjung Tilah Empak Bau) Sasak Tribe Lombok Island West Nusa Tenggara is more effective and has a pull to be able to improve student learning outcomes. Evidenced by the results of $t$ count $=10.89$ while $t$ table $=1.69$. Because $t$ arithmetic is greater than $t$ table then Ho is accepted. So that local wisdom-based teaching materials (AIQ Nyereng Tunjung Tilah Empak Bau) can be used in learning.

The effectiveness and feasibility of local wisdom-based teaching materials in Jepara Regency were also obtained from the results of the teacher's questionnaire responses. Based on the questionnaire results, the teacher obtained a total score of 684 , an average of 3.8 percentages, $95 \%$ with a very good category. At the beginning of teaching materials namely learning instructions and competencies that must be achieved obtain an average score of 3.9 and 4 . This implies that teaching materials are easy to use by teachers because the learning instructions are very clear, between core competencies, basic competencies, indicators, and learning objectives in accordance with the material presented.

At the core of the teaching material which includes the content of the material, the exercises gained an average score of 3.5 to 4 . This shows that the material in the teaching material illustrates the characteristics of thematic learning that is holistic, active, authentic, meaningful, using language that is in accordance with the level of cognitive and emotional development of students. For independent activities, joint activities and practice questions are also clear and appropriate. So it can be concluded that Jepara's local wisdom-based teaching material is already appropriate to be used as one of the teaching materials in thematic learning activities. In line with the opinion of Zinnurain \& Muzanni (2018) based on the results of his research stated that teaching materials based on local wisdom can be used as one of the textbooks in thematic learning activities in primary schools because the results of questionnaire instruments and tests get scores with very good categories.

Based on the questionnaire responses of students obtained a total score of 473 an average of 3.9 percentage $98 \%$ with a very good category. So it can be concluded that the teaching materials based on local wisdom in Jepara Regency are feasible to be used in thematic learning. For student responses and comments, this teaching material is interesting, easy to understand and encourages learning. In line with the results of research Damayanti, et al (2013) which states that learning based on local wisdom can increase student interest and learning outcomes and be able to increase students' love for the local culture in the environment around students

\section{Conclusion}

The conclusions in this study are as follows: 1) The needs of students and teachers in supporting an active and meaningful learning process are teaching materials based on local wisdom in Jepara Regency. 2) The validity of teaching materials based on Jepara's local wisdom in terms of material and language scores 91 an average of 3.64 percent $91 \%$ with a very good category. From the aspect of the media obtained a score of 54 on average 3.6 percentage of $90 \%$ with a very good category. The results of the teacher's response gained a score of 684 on average 3.8 percentages $95 \%$ with very good categories. The results of 
student questionnaire responses obtained a 157 total score of 3.9 percentage $98 \%$ with a very good category. 3) The effectiveness of Jepara's local wisdom-based teaching materials is obtained from the results of the t-test in the experimental and control groups of 11.036. Data from the $t$ test shows that $t$ arithmetic $>t$ table is $11.036>1.969$ then Ha is accepted.

Based on the results of research and development, it can be concluded that Jepara's local wisdom-based thematic teaching materials are effective and appropriate for use in learning. So it can be used as a source of learning for teachers to improve learning outcomes and instill a sense of love for students of local wisdom where they live.

\section{References :}

[1] Damayanti,C.Dewi,N.R,Akhlis,I. Pengembangan CD Pembelajaran Berbasis Kearifan Lokal Tema Getaran dan Gelombang Untuk Siswa SMP Kelas VIII. Jurnal Pendidikan Sains. Semarang: FMIPA Universitas Negeri Semarang (2019)

[2] Duncan,M. How The Culture Context of Urban Teaching Affect Novice Science Educators:Implications for School Leaders. International Journal of Educational Leadership Preparation, 9 (1), 1-17 (2014)

[3] Hidayati, Deny. Memudarnya nilai Kearifan Lokal Masyarakat dalam Pengelolaan Sumber Daya Air. Pusat Penelitian Kependudukan. Lembaga Ilmu Pengetahuan Indonesia (2016).

[4] Kasa,L.W.Local Wisdom In Relation To Climate Change. J.ISSAAS,17 (1):22-27 (2011)

[5] Meliono, Irmayanti. Understanding The Nusantara Thougt and Local wisdom As An Aspect of The Indonesian Education. Tawarikh International Journal For Historical Studies, 2 (2):221-234 (2011)

[6] Miles,M.B., \& Huberman,A.M. 2014. Qualitative data analysis, a methods sourcebook, Los Angeles:Sage Publication Ltd.

[7] Muktadir, Abdul. 2017. Efektivitas Model Bahan Ajar Mulokberbasis Cerita Rakyat Untuk Pendidikan Karakter Di Sd. In: Prosiding Seminar Nasional Pendidikan Guru Sekolah Dasar "Pembelajaran Literasi Lintas Disiplin Ilmu Ke-SD-An", 4 - 6 September 2017, Bukittinggi, Indonesia (2017).

[8] Mungmachon,R. 2012. Knowledge And Local Wisdom : Community Treasure. International Journal Of Humanities And Social Sciences. Vol.2 No.13. 174-181 (2012)

[9] Northcote,M.,Kilgour,P.,Reynoud,D.,\&Fitzsimmons,P.Engaging in Deep Cultural Learning trough the Intersection of Multiple Contexts. Australian Journal of Teacher Education,39(10),47-63 (2014)

[10] Oktavianti, Zuliana, Ratnasari.Menggagas Kajian Kearifan Budaya Lokal Di Sekolah Dasar Melalui Gerakan Literasi Sekolah. Kudus : FKIP Universitas Muria Kudus (2017)

[11] Saidah,R. Krisis Regenerasi Pengukir Muda dan Eksistensi Kearifan Budaya Ukir Jepara (Studi Kasus di Desa Mulyoharjo, Kabupaten Jepara). Jurnal Ilmiah. Universitas Negeri Semarang. Vol.44.No.2 ISSN 1412-971X (2017)

[12] Setiawan, Benni. 2008. Agenda Pendidikan Nasional. Yogyakarka : Ar-Ruz Media Group

[13] Shufa,N.K.F.(2018). Pembelajaran Berbasis Kearifan Lokal di Sekolah Dasar:Sebuah Kerangka Konseptual. Indopendas Jurnal Ilmiah Kependidikan Vo.1No.1. Kudus:Universitas Muria Kudus.

[14] Sugiyono, 2016.Metode Penelitian dan pengembangan (Research and Development).Bandung : Alfabeta.

[15] Suherman, 2016. Pengembangan Bahan Ajar Berbasis Kearifan Lokal (AIQ Nyereng Tunjung Tilah Empak Bau) Pada Tema Mengenal Lingkungan Alam Sekitar Di 
Kelas III MI Mambaul Khair Kota Mataram. Tesis. PGMI Pascasarjana Universitas Islam Negeri Maulana Malik Ibrahim Malang.

[16] Suyitno.I,Suherjanto.I,Sunoto,Kamal,M.(2015) Pemanfaatan Potensi Kearifan Lokal dalam Pembelajaran dengan Teknik Observasi Lingkungan di Sekolah Dasar. Jurnal Ilmiah. Malang:Universitas Negeri Malang.

[17] Tanjung, A dan Fahmi,M. 2016. Urgensi Pengembangan Bahan Ajar Geografis Berbasis Kearifan Lokal. Jurnal Pendidikan Geografi Th.20.No.1. Universitas Negeri Malang.

[18] Utari,U. 2016. Pengembangan Bahan ajar Tematik Berbasis Kearifan Lokal BugisMakassar Untuk Siswa Kelas III Sekolah Dasar. Tesis. Malang: PGSD Pascasarjana Universitas Negeri Malang.

[19] Zinnurain, Muzanni,A. 2018. Pengembangan Bahan Ajar Berbasis Kearifan Lokal Pada Siswa Kelas V Sekolah Dasar. Jurnal Ilmiah IKIP Mataram. Dosen Fakultas Ilmu Pendidikan IKIP Mataram 